\title{
Exploring Integrated Language in Use for Undergraduate English Learners through Wayang Stories
}

\author{
Hermayawati \\ hermayawati@mecubuana-yogya.ac.id \\ Universitas Mercu Buana Yogyakarta, Yogyakarta, Indonesia
}

\begin{abstract}
Teaching integrated English skills has been currently becoming a crucial discussion among the teachers in line with the changing of the view about language use. The problem is, how to deliver it due to the limited time allocation (two Semester Credit Unit) per-week with the large amount of materials content. This paper explores the procedure on delivering the four integrated English skills through Wayang stories as the learning materials by involving 40 undergraduate level of English I learners. The data compiled using in-depth observation and integrated skills tests through the given tasks were analyzed both descriptively and numerically. Result of indepth observation mainly reveals the WUPPA (watching, understanding, paraphrasing, performing and assessing) procedures and its benefit to teach integrated skills learning conceptually. Wayang stories were utilized to educate learners to love their cultures through acquiring the hidden moral messages embedded in each story. Findings show that WUPPA procedures gained relatively moderate achievements due to most learners attained competent (33\%) and very competent level (61\%) of their language proficiencies. It was only a small part of them (6\%) who achieved the 'Not yet competent' level. Finally, this study provides an alternative to teach integrated English skills using wayang stories with WUPPA that do not only enrich teaching materials as it makes the learners enjoyable and insightful but also can be used to embed moral values education.
\end{abstract}

Keywords: integrated skills, learning materials, wayang stories, WUPPA, in-depth observation

\section{INTRODUCTION}

Teaching Integrated Language Skills including English has been currently being under-discussed among the relevant teachers. This case is due to the change of the linguists' views about language and its teaching either to the users or learners. The change of course, must be followed by the relevant institution, especially English Study Program Universitas Mercu Buana Yogyakarta. Such appeared issue is mainly triggered by the existence of English allotted time which is considered very limited by remembering that the position of English Education is as an EFL (English as a Foreign Language) and not as an ESL (English as a Second Language). This is for the Indonesian government both political and historical judgment due to this country has decided the second language is the Indonesian language as decided on the Indonesian Youth Pledge October 28, 1928

The current Indonesian Education Curriculum (IEC) for undergraduate level decided that English is taught only in two SCU (Semester Credit Unit). In higher levels this foreign language is commonly taught into two Semesters id est. English I and English II courses 
(Kemenristek Dikti, 2017). The first course is taught as General English in the first semester while the second is in the third and some in the seventh as ESP (English as a Specific Purposes) course. This paper explores the procedure on teaching English I (General English) in undergraduate level involving 40 students for seven meetings. Each meeting is delivered by activating the learning process through integrated skills technique.

This paper is a report of an exploration project involving 40 learners of English I (General English) course conducted at Universitas Mercu Buana Yogyakarta. In the aforementioned university, English I course is currently addressed to the first semester students and English II or ESP (English for Specific Purposes) is mostly learnt by the third semester students. There is a faculty which schedules ESP for the seventh semester students. This study purposively involved an English I (General English/GE) course class with various level of English proficiency since they come from various regions and English proficiency levels. In this case, learners were treated as a group of 'threshold level' English class. Van Ek (1972) defines 'threshold level' of English, as a level of English proficiency for those who have been studying English for many years but keep unable to use it to communicate with foreigners. The learners were grouped into such English proficiency level by considering that most of them were factually could not use English as a means of communication, even in the English course class. Based on such reasons, the learning process utilized human puppets performed in the 'YouTube' in Javanese speeches and in Indonesian language (provided in the running text form).

Cumming (2013) interpreted IES (Integrated English Skills) as an ISE (Integrated Skills of English) as follows: ISE is an all four language assess exams skills - reading, writing, speaking and listening-in a way that reflects real-life communication in English. Based on this understanding, the form of IES learning is by combining the four skills of reading, writing, speaking and listening at once by directly reflecting it in actual communication (Tosuncuoglu, 2018). Gebril (2018) integrates the language skills of reading with writing by providing the short answer questions following the reading passages contain new language aspects such as structure, grammar, vocabulary with its spelling. Such linguistic features are, then, developed as the basis of learners writing skill using their own idea.

Integrated English skills is, in this case, a technique utilized to deliver the four language skills for the intention of enhancing learners' language proficiency both through enriching the language aspects (grammar, structure, vocabulary, spelling, pronunciation and comprehension) and the target language content related to the course topics as suggested in the Syllabus. The target content consists of seven wayang orang (WO) stories 
adopted from the Ramayana and Mahabharata stories. WO stories are utilized as the consideration that they contain samples of good (the knights) and also bad attitude (the wicked person) as actualization of human daily life, besides as a means of introducing the priceless ancestors' heritage as it is implied in the Presidential Regulation No. 8/2012 regarding KKNI (Kerangka Kurikulum Nasional Indonesia) or IQF (Indonesian Qualification Framework.

Referring to the aforementioned issues, this paper is intended to explore the undergraduate English learners' capacities in acquiring the four English skills such as: listening-speaking-reading-writing in integrated way with the selected wayang stories as its materials contents. In this case, human puppets (Javanese: wayang orang) stories were employed as the learning content for it is known that Wayang (including human puppets) has been recognized as one of the world's "Masterpiece of Oral and Intangible Heritage of Humanity" by UNESCO (Wayang Indonesia, 2010; Lestari, 2014; Runnisa, 2018). Therefore, it is ironic if a cultural product recognized as a world cultural treasure but is not well-known by the members of the cultural owner's community including the higher-level learners.

Cultural Language Learning Approach (CLLA) is a nature of language learning process in acquiring language being learnt through knowledge acquisition about culture of a certain language users' community (Setiadi, 2017). Every community or nation has its own unique culture as the result of the interpretation of the human mind to fulfill the purposes and activities of life (Ramli, 2017). In this case, CLLA was employed as an approach of language learning by using traditional cultures as the learning materials with the intention of introducing and conserving the target cultures, namely WO performance series as the online media that were accessed in integrated way with Blended Learning Method (BLM) to customize the students' High Order Thinking Skills (HOTS) capacities. Smith \& Hill (2019) defined BLM as learning systems that "combine face-to-face instruction with computer mediated instruction" including to enhance the four language learning skills as well as autonomous learning and learner motivation (Banditvilai, 2016). It is delivered by utilizing the selected on-line materials as the source of classroom learning (Thompson, 2016) besides as an array of teaching methods, that can be accessed through the new technology (Oliver, 2005; Ginaya et al., 2018). In this study, BLM was employed as it offered greater efficiency in the communication and practice of the language target being learnt (Tawil, 2018). 
High Order Thinking Skills (HOTS) is a concept which distinguishes critical thinking skills from low-order learning outcomes, such as those attained by rote memorization. The critical thinking skills include synthesizing, analyzing, reasoning, comprehending, application, and evaluation. HOTS refer to various taxonomies of learning created by Benjamin S. Bloom in his 1956 book, "Taxonomy of Educational Objectives: The Classification of Educational Goals." HOTS are reflected by the top three levels in Bloom's Taxonomy: analysis, synthesis, and evaluation (Watson, 2019), which then, was revised into: analysis, evaluation and creation. Previous studies revealed that HOTS was effective to train student's thinking skills in accordance with the level of each student's thinking. In this study, HOTS were benefitted to customize the students' integrated language skills learning process using CLLA and BLM for the materials were adopted directly from the You Tube through their gadgets.

Practically, CLLA, BLM, and HOTS were employed together by watching, understanding, paraphrasing, performing or presenting, and assessing (WUPPA) procedure. WUPPA procedure involved the use of CLLA, BLM, and HOTS since such activities involved understanding (listening) each WO story performed in Javanese: language, costumes, songs, orchestra (CLLA) that were accessed online through You Tube to discuss (BLM). After understanding (which was indicated by their ability to answer the provided questions given in the tasks), the content supported through the available running texts (reading), they were then, asked to paraphrase the content using their own English words (writing) and finally presenting the works in groups orally (speaking). During the discussion, the other fellow groups evaluate each group presentation by using the decided scoring rubrics as a matter of learning assessment. Such WUPPA activities of course, need learners' HOTS abilities.

\section{METHOD}

The project employed a mixed-design. Both qualitative and quantitative data were analyzed descriptively and statistically. The qualitative data which was mainly in the form of in-depth observation results on the learners' learning process for six meetings were analyzed descriptively and the portfolio of tasks score results were statistically analyzed using Sheppard Scoring Rubrics as the measurement standard Sheppard (2019) and Aiken's $V$ formula (Yulkifli et al., 2019) as the data validation. There are three types of mixed research, namely triangulation, explanatory and exploratory designs (Sanjaya, 2013). Triangulation design is categorized into four models, namely conference, data 
transformation, data validation and multilevel models. This study uses the Convergence Model of Triangulation Design, where the quantitative and qualitative data are collected and analyzed using each employed approach. The outcome is, then, compared and interpreted (Sanjaya, 2013). Figure 1 illustrates the procedure for implementing a Convergence Model.

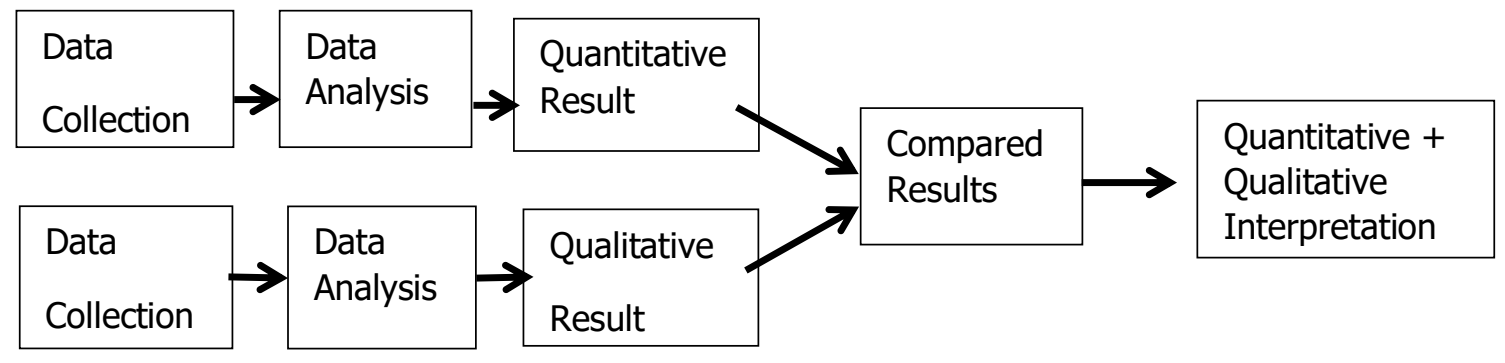

Figure 1. Convergence Triangulation Design Model (Sanjaya, 2013)

The qualitative data was analyzed descriptively using scoring rubrics for they can cover both reliability and validity issues. Rubrics perform a series of scores, each of which illustrates a concrete observable terms description of what a performance at a given level should look like (Sheppard, 2015). Table 1 performs Sheppard model of Single-Criterion Rubrics Design which is used to score learners integrated skills.

Table 1. Single-Criterion Rubrics Design (Sheppard, 2015)

\begin{tabular}{cl}
\hline Score & \multicolumn{1}{c}{$\begin{array}{c}\text { Skill } \\
\text { (Communicability in forming negative statements) }\end{array}$} \\
\hline $\mathbf{0}$ & $\begin{array}{l}\text { No response; response incomprehensible; response unrelated to prompt; no } \\
\text { observable attempt to make a negative statement } \\
\text { Language use demonstrates some emerging understanding of the feature but }\end{array}$ \\
$\mathbf{1}$ & $\begin{array}{l}\text { communication is impeded or labored due to problems with syntax, auxiliaries, S-V } \\
\text { agreement, etc. }\end{array}$ \\
$\mathbf{2}$ & $\begin{array}{l}\text { Language use is generally comprehensible but some of nuances of meaning may be } \\
\text { unclear due to problems with syntax, auxiliaries, S-V agreement, etc. }\end{array}$ \\
$\mathbf{3}$ & $\begin{array}{l}\text { Language use is entirely comprehensible but marked as non-native due to } \\
\text { irregularities in syntax, auxiliaries, S-V agreement, etc. }\end{array}$ \\
$\mathbf{4}$ & Language use is Native-like use \\
\hline
\end{tabular}

The Single-Criterion Rubrics Design (SCRD) provides 4 level of scoring rubrics showing the four level categories of the learners' English proficiency in a whole unlike the conventional isolated language skills such as scoring rubrics for: listening, speaking, reading and writing. In other words, SCRD is particularly addressed to score learners integrated language skills. The four skills are packed as a unit of linguistic features embedded with the contextual, topical discourses in which contents are human puppets stories of Ramayana and Mahabharata series learnt from the YouTube using Blended Learning Method (BLM) 
and Cultural language Learning Approach (CLLA). Both BLM and CLLA were, in this study, employed in integrated way through the selected WO stories that especially contained the unique Javanese culture products such as the Mahabharata and Ramayana serial stories, the costumes, the dances, the speeches and the valuable moral messages. All the unique Javanese cultural heritages were accessed and blended as the learning materials to study in the class forum in groups.

The learning activities lasted through watching the selected video of wayang stories to understand, analyze, evaluate, and then, each story was utilized as the basis or source to use the language targets being learnt. Such integrated learning, of course needs High Order Thinking Skills (HOTS) but appropriately with the learners' intakes. HOTS involves the three high levels of learners' thinking connected with their levels in analyzing, evaluating and creating (Sukmadinata, 2007; Merta et al., 2017). All of the learning processes conducted in groups of 5, were deeply observed and scored using Sheppard Single-Criterion Rubrics as shown at Table 1 . The table performs five criterion used as the basis of scoring learners' language use activities. The scores are stretched from 0 (zero) to 4 (four) as the scoring rubrics. Each numerical score has its own level of language use capacities. Score 0 will be achieved if the learners group does not have any response, response incomprehensible, response unrelated to prompt, and there is not observable attempt to make a negative statement. Score 1 can be reached if learners use some emerging understanding of the feature but communication is impeded or labored due to problems with syntax, auxiliaries, S-V agreement, et cetera. Score 2 can be reached if learners language use is generally comprehensible but some of nuances of meaning may be unclear due to problems with syntax, auxiliaries, S-V agreement, et cetera. Score 3 can be reached if learners language use is entirely comprehensible but marked as non-native due to irregularities in syntax, auxiliaries, S-V agreement, et cetera. Score 4 is possible to gain if the learners use the language target as Native-like use (Table 1).

The gathered qualitative data were in the forms of the results of in-depth observations towards the English use learning process (utilizing BLM, CLLA and HOTS) and the learners' understanding both on the whole materials content and the target linguistic features such as: the integrated language use and its components (grammar, structure, vocabulary, spelling and pronunciation). The quantitative data was analyzed using Aiken's $V$ with assessment benchmarks stretching from 1-5 scores. But in this project, the score was intentionally simplified into $1-4$ scores with respectively categories of: 'not yet competent (score 1)', 'competent (score 2)', 'very competent (score 3)' and 'sophisticated (score 5)'. 
This project employed two inter-raters in examining the learners' scores validity and the results were analyzed using the Aiken's V formula, then, were averaged as a single score for each learner. The following is the Aiken's $V$ formula used to assess the learners' portfolio English tasks scores:

$$
\mathrm{V}=\Sigma \mathrm{S} /[\mathrm{n}(\mathrm{C}-1)]
$$

where $V$ is Validity coefficient, $S$ is $r-I_{0}, n$ is total number of assessors, $r$ is score given by an assessor (inter-rater), $\mathrm{S}$ is subject matter inter-rater who gives score, $\mathrm{I}_{0}$ is the lowes validity score [1], $\mathrm{C}$ is the highest validity score [5]. Assessment benchmarks stretching from [1-5].

\section{RESULTS AND DISCUSSION}

This study reveals the results of exploration on the learners' integrated English in use learning process by utilizing WO story serials embedded with the target linguistic features of both skills and components completed with its achievement in WUPPA procedures that was performed through CLLA, BLM and HOTS. The following is the results of this study and its analysis.

\section{Procedures on Delivering Integrated English Skills in Use}

As it is conceptually known that language teaching involves the four language skills that formerly taught in isolated way, or learnt for each skill in 1980s until 2013. But in its development, language learning has shifted in line with the needs of the times and its users. Current learning has referred to the use of language as a communication tool that is in accordance with the context of its use, namely the competing skill between linguistic features and the content of the discourse. Therefore, to combine these two variables, this study uses a series of sequent activities, namely: watching, understanding, paraphrasing, performing or presenting, and assessing (WUPPA) procedure for each learning session.

This project lasted within six sessions (7 course meetings) by using two serials of both Ramayana and Mahabharata with three and four stories for each. The stories entitle 'Shinta Murca', 'Sugriwa and Subali', Kumbokarno Gugur' (The Ramayana), 'Pandu Dewanata Gugur', 'Karno Sumbogo', 'Pandawa Dadu', and 'Pandowo Boyong' (The Mahabharata). Those stories are intentionally selected to embed moral values in the 
learners' learning process besides to enhance their integrated language skills use and HOTS acquisition all at once.

To simplify the description, the WUPPA learning procedures were separated into two groups of materials that were selected based on the series types. Three stories were selected from the Ramayana series, namely: 'Shinta Murca', 'Sugriwa and Subali' and Kumbokarno Gugur' that were delivered into three sessions. From the Mahabharata series, four stories were taken as the teaching materials, namely: 'Pandu Dewanata Gugur', 'Karno Sumbogo', 'Pandawa Dadu' and 'Pandowo Boyong' that were taught for four sessions.

The descriptive data shown in Table 2 generally indicates that the learning procedures using WUPPA have gained learners' enhancement in their integrated skills learning processes.

Table 2. WUPPA stages realization in a whole and the results

\begin{tabular}{|c|c|}
\hline Stage & Results \\
\hline $\begin{array}{l}\text { 1-3 Ramayana } \\
\text { Series 'Shinta } \\
\text { Murca', } \\
\text { 'Sugriwa and Subali', } \\
\text { Kumbokarno Gugur' }\end{array}$ & $\begin{array}{l}\text { 1. Up to three times WUPPA activity meetings lasted in group of 5, the } \\
\text { learning processes running smoothly with no difficulties in accessing } \\
\text { material from YouTube. However, learners seemed to have difficulty in } \\
\text { understanding the characters' interpersonal conversations for their } \\
\text { Javanese speeches. However, they were supported by the running texts } \\
\text { accompanied the video. } \\
\text { 2. The majority of learners did not seem to have difficulty in understanding } \\
\text { the contents of each story and its each embedded moral values hidden } \\
\text { messages. } \\
\text { 3. Almost all learners experienced difficulties in conveying the stories both } \\
\text { in oral and written terms which were apparently caused by their } \\
\text { limitations in using the linguistic features and writing coherency. }\end{array}$ \\
\hline $\begin{array}{l}\text { 4-7 Mahabharata } \\
\text { Series: } \\
\text { Pandu Dewanata } \\
\text { Gugur', 'Karno } \\
\text { Sumbogo', } \\
\text { 'Pandawa Dadu', } \\
\text { 'Pandowo Boyong' }\end{array}$ & $\begin{array}{l}\text { 1. In these stages } 1 \text {. The WUPPA process at this stage of learning began to } \\
\text { gradually improve as a whole. } \\
\text { 2. The majority of learners understood the storyline and were able to } \\
\text { communicate the contents of each story in English to the group and to } \\
\text { the instructor even though they still used simple language features. } \\
\text { 3. The majority of learners seemed to be gradually confident when } \\
\text { displaying the contents of puppet stories both verbally and in writing } \\
\text { although sometimes they had not used the narrative language features } \\
\text { correctly and consistently. }\end{array}$ \\
\hline
\end{tabular}

The WUPPA delivers integrated skills by respectively provide listening through Watching the selected video, Understanding the available running text, paraphrasing by rewriting the content using the learners' own words, $\mathrm{P}$ (resenting/Performing) the text in oral way by retelling the content through the text they have created, and the last is Assessing their own works in groups of five. Self-assessment process was conducted in groups of five by under-guidance of the classroom instructor that was, then, followed by giving feedback on the groups' assessment results. In this case, the four language skills were delivered in integrated way, and only focused on the selected 
topics of human puppets series. The WUPPA procedures which were employed in this study were successfully attracting the learners in depth learning involvement. This was due to their getting new experiences towards the materials content they watched, besides the new linguistic features they acquired. As research participants, learners also acquired experiences in conducting self-assessment using Sheppard scoring rubrics that they had previously never done.

\section{Learners' Integrated Skills Learning Achievement using Sheppard (2019) Scoring Rubrics}

In case of the assessment term in the WUPPA procedures using Sheppard scoring rubrics as employed in this study, most learners were appropriately categorized into 'competent' language proficiency while the rest belong to 'very competent' and 'not yet competent. None attained the 'sophisticated' category. To make easier to percentage, those categories were conversed into the following scores: 'sophisticated $(A)^{\prime}$ ' is similar to $85-100$ scores, 'very competent $(B)^{\prime}$ ' is similar to $75-84$, 'competent (C)' is similar to 65-74, and 'not yet competent (D)' spreads between 50-64. Fifty is considered as the poorest score since the undergraduate learners must have ever learned English for many years so that they have acquired a lots of linguistics features previously. In other words, they deserve to have at least minimal score for their previous learning achievements.

By using conversion as mentioned above, among 40 learners, there were 13 persons or $13 \%$ reached 'very competent', 24 persons or $61 \%$ got 'competent' proficiency, and 3 persons or $6 \%$ achieved 'not yet' levels. None or $0 \%$ achieved the 'sophisticated' category. This means, that the average portfolio results of the integrated English learning show that the majority of learners have got the same ability, while the rest acquired integrated English proficiency upper and lower than the class average. The learners' integrated skills learning achievement using Sheppard (2018) Scoring Rubrics are performed in Table 3.

Table 3 shows the average score of tasks portfolio distribution on integrated English skills involving 40 learners. The scoring rubrics were employed as the benchmark to assess seven times of learners' tasks. Sheppard (2018) uses 5 scores level that starts from 0 (null) to 4 (four) respectively. Learners can achieve score 4 if they are able to use English in integrated way like native speakers. They must use all language features correctly. They will be scored 3 if they use the integrated skills entirely comprehensible even though marked as non-native due to irregularities in syntax, auxiliaries, S-V agreement, etc. Score 2 and 1 can be reached when they respectively use English 
generally comprehensible even though some of nuances of meaning may be unclear due to problems with syntax, auxiliaries, S-V agreement, et cetera, and they are able to demonstrates some emerging understanding of the feature though communication is impeded or labored due to problems with syntax, auxiliaries, S-V agreement, etc. This study did not use the null score by considering that the learners' intakes on English are various so that they are treated as the 'false-beginners' English level. They are treated as such level for they have learnt English for many years but most of them keep unable to use it as a means of communication with foreigners (Van Ek, 1972).

Table 3. Average of Portfolio Distribution of Integrated English Skills Involving 40 learners

\begin{tabular}{|c|c|c|c|c|}
\hline $\begin{array}{c}\text { Scoring Conversion } \\
\text { Category }\end{array}$ & $\begin{array}{l}\text { Score } \\
\text { Number }\end{array}$ & Scoring Criteria & $\begin{array}{l}\text { Learners' } \\
\text { Average } \\
\text { Score }\end{array}$ & Percentage \\
\hline $\begin{array}{l}\text { Sophisticated (A) Score } \\
85-100\end{array}$ & 4 & Native-like use & 0 & $0 \%$ \\
\hline $\begin{array}{l}\text { Very Competent (B) } \\
\text { Skor 75-84 }\end{array}$ & 3 & $\begin{array}{l}\text { Use is entirely comprehensible } \\
\text { but marked as non-native due } \\
\text { to irregularities in syntax, } \\
\text { auxiliaries, S-V agreement, etc. }\end{array}$ & 13 & $33 \%$ \\
\hline $\begin{array}{l}\text { Competent (C) Skor 65- } \\
74\end{array}$ & 2 & $\begin{array}{l}\text { Use is generally comprehensible } \\
\text { but some of nuances of } \\
\text { meaning may be unclear due to } \\
\text { problems with syntax, } \\
\text { auxiliaries, S-V agreement, etc. }\end{array}$ & 24 & $61 \%$ \\
\hline $\begin{array}{l}\text { Not Yet Competent (D) } \\
\text { Skor } 50-64\end{array}$ & 1 & $\begin{array}{l}\text { Use demonstrates some } \\
\text { emerging understanding of the } \\
\text { feature but communication is } \\
\text { impeded or labored due to } \\
\text { problems with syntax, } \\
\text { auxiliaries, S-V agreement, etc. }\end{array}$ & 3 & $6 \%$ \\
\hline
\end{tabular}

\section{Qualitative Data Analysis}

As it has been previously mentioned that this study employed Convergence Triangulation Design Model (CTDM). In using such model, the data interpretation is mixed between the qualitative and the quantitative data (Sanjaya, 2013). The qualitative data of this study were in the forms of the results of in-depth observations towards the English use learning process (utilizing BLM, CLLA and HOTS) and the learners' understanding both on the whole materials content and the target linguistic features such as: the integrated language use and its components (grammar, structure, vocabulary, spelling and pronunciation) through WUPPA procedure. Result of the qualitative data analysis showed that the WUPPA procedure was successfully used to teach the four English language skills in an integrated manner and more efficient in its use. In addition, the learning content in the form of puppet shows with Ramayana and 
Mahabharata series can be understood and can enrich the cultural insights of learners who previously did not really know their own culture.

\section{Quantitative data analysis}

The quantitative data which were in the forms of learners' groups' numerical scores learning achievements were analyzed by employing Sheppard Scoring Rubrics. Result of quantitative data analysis indicate that a series of portfolio tasks done by the learners using WUPPA procedures gained relatively moderate achievements due to most learners attained competent (33\%) and very competent level (61\%) of their language proficiencies. It was only a small part of them (6\%) who achieved the 'Not yet competent' level (Table 3). This means that the selected WO stories utilized in the English integrated skills learning process using WUPPA procedures is considered not only appropriate to explore the learners' English skills in integrated manner but also can enrich their insights on WO stories as one of their own national cultures. Another more beneficial matter is, that the WO stories implicitly educate the learners to behave normative life manners.

Referring to the aforementioned project findings, English I Course, which in Universitas Mercu Buana Yogyakarta (UMBY) has been taught as General English, should be varied with WO serial stories as the source content by considering that introducing both the culture performances and the stories content that full of moral messages (Widyastutieningrum, 2018). In this study, the materials content was adopted from the Ramayana and Mahabharata stories mainly played by the popular human puppets groups such as Sekar Budaya Nusantara, Sri Wedari and RRI Surakarta Groups. All performances are available in the YouTube site. From the Ramayana Serial stories, the selected titles were 'Shinta Murca', 'Sugriwa and Subali', Kumbokarno Gugur' while the Mahabharata series used as the materials topics were 'Pandu Dewanata Gugur', 'Karno Sumbogo', 'Pandawa Dadu', and 'Pandowo Boyong'. Those stories were purposively selected for their embedding high level of moral messages that are crucially needed to educate the learners' attitudes. As it is known that today's learning materials should involve the three education domains such as cognitive, affective or attitude and psychomotor or skills (Kemenristekdikti, 2017).

Previous supported studies indicated that most teachers agree that teaching the culture of native speaking countries is valuable, for it motivates students to find more information on their own. This is due to the fact that in communication culture plays an important role (Nguyen, 2017). This means that speaking about the target culture is 
better and it is not harm (Miladinović, 2016), though in facts, it's learning percentage still should be considered (Marek, 2014). This should be taken into account, for previous study of Nguyen (2017) revealed that there was a textbook published in 2003 in Indonesia, contained 15 units listed as follows: Our Capital City: Becak; We Love Dangdut, Harmonious Life; Students and Brawls; Preserving the Tradition: Textiles; Rendra; The World of Mistism; Business Matters; Traditional Wedding Ceremonies; Traditional Arts: Wayang; Wanted Urgently: Are you the Right Person?; The Top Five; Caring for Fauna; and Indonesian cuisine: Ayam Taliwang. According to Nguyen (2017), the textbook fulfilled the goal of preparing students to talk about their own cultures to others, to emphasize local cultures, and to reflect the needs of Indonesians to talk about such various cultural aspect owned by Indonesia.

Judging from its contents, the textbook displays the discourse of Indonesian culture as a whole, even if only performing each unit at the surface level, including the unit about 'Wayang'. This study did not investigate about what to teach but much more focused on how 'Wayang' particularly 'Wayang Orang (WO)' can be utilized as a media both to introduce WO and it's moral messages embedded in each of the stories. Culture and moral education are extremely needed to arouse students' attitudes as it is demanded by Presidential Regulation No. 8/2012 regarding the Indonesian Qualification Framework (IQF). IQF mainly mandates the higher level graduates will achieve six aspects, namely as follows: (1) Devotion to God Almighty; (2) Having good morals, ethics and personality in completing their duties; (3) Acting as a proud, loving fellow Indonesian citizens, and supporting world peace; (4) Being able to work together, having high social sensitivity, concerning for the community and the environment; (5) Respecting the diversity of cultures, views, beliefs and religions as well as other people's original opinions / findings; and (6) Upholding the rule of law, having a passion to put the interests of the nation, and prioritizing the wider community interest (Nur, 2019). Without intention of ignoring on the other aspects, this research mainly focuses on the second aspect, namely arouse the students on 'Having good morals, ethics and personality in completing their duties', by introducing moral values embedded in the WO serials which are presented in integrated-skills using CLLA and BLM as an effort to customize the students' HOTS practices.

There are two things that benefit from using WUPPA as an integrated skill learning procedure. Firstly, it is from the linguistic side that they get practical language skills completed with the acquisition of language features efficiently, since the skills are not 
learnt in isolated way. Secondly, the content of materials embedded with moral values trains them to habitualize the use of high-level thinking (HOTS). HOTS can increase their intelligences (Irvine, 2017; Ichsan et al., 2019). There are five ways to increase human intelligence, namely: seeking novelty, self-challenge, thinking creatively, doing things in the hard way and networking (Siorpaes, 2010). Siorpaes also argues that the more training, the more once gain. Such training habit is to enable the learners to emphasize their way of thinking to the aforementioned five areas. In this case, they will be able to critically engage in analyzing, evaluating and creating something new and insightful when they do so (Abosalem, 2016).

\section{CONCLUSION}

The development of language teaching has currently demanded learning process that focuses on communicative language use. The WUPPA is an alternative procedure that can be used as a model for teaching language in an integrated way started from listening to writing. The learning materials can be variously taken from any sources to fulfill the learners' target linguistic features acquisition including Wayang stories performance (human puppets show) available in the YouTube. Wayang stories cannot only be used to teach the target linguistic features but can also be used as a means of character education for learners. Character education has been largely ignored by teachers including of higher education level. In fact, education should develop three learning domains in a complete and integrated manner, namely cognitive, affective and psychomotor which in language learning can be delivered in imbedded, not in isolated way.

\section{REFERENCES}

Abosalem, Y. (2016). Assessment techniques and students' higher-order thinking skills. International Journal of Secondary Education, 4(1), 1.

Banditvilai, C. (2016). Enhancing students language skills through blended learning. Electronic Journal of e-Learning, 14 (3), pp223-232.

Cumming, A. (2013). Assessing integrated skills. The companion to language assessment, 1, 216229.

Gebril, A. (2018). Integrated - Skills Assessment. The TESOL Encyclopedia of English Language Teaching, 1-7.

Ginaya, Gede., Rejeki, I Nyoman Mei., Sri Astuti, Ni Nyoman. (Januari, 2018) The Effects of Blended Learning to Students' Speaking Ability: A Study of Utilizing Technology to Strengthen the Conventional Instruction. International Journal of Linguistics, Literature and Culture Vol. 4 (3) pp. 1-14 doi: $0.21744 /$ ijllc.v4i3.661

Ichsan, I. Z., Sigit, D. V., Miarsyah, M., Ali, A., Arif, W. P., \& Prayitno, T. A. (2019). HOTS-AEP: Higher Order Thinking Skills from Elementary to Master Students in Environmental Learning. European Journal of Educational Research, 8 (4), 935-942. 
Irvine, Jeff. (2017) "A Comparison of Revised Bloom and Marzano's New Taxonomy of Learning." Research in Higher Education Journal 33 (2017).

Kemenristek Dikti. (2017). Rekognisi Pembelajaran Lampau. Available June 13, 2017 from https://www.ristekbrin.go.id/pengumuman/rekognisi-pembelajaran-lampau/

Lestari, Wahyu. (March, 2014). The Philosophy of Puppet Characters Bathara in Murwakala Play for the Value of Leadership Ethics. Harmonia: Journal of Arts Research and Education 14 (1) pp. 8-15. Retrieved August 7, 2019 from https://journal.unnes.ac.id/nju/index.php/harmonia/article/viewFile/2785/2836

Marek, Michael W. (2014). In teaching English as a Foreign Language, how much of the class should be about culture? Retrieved May 14, 2020 from https://www.researchgate.net/post/.

Merta Dhewa Kusuma, Undang Rosidin, Abdurrahman, Agus Suyatna. (January, 2017). The Development of Higher Order Thinking Skill (HOTS) Instrument Assessment in Physics Study. IOSR Journal of Research \& Method in Education (IOSR-JRME) Vol. 7(1).

Miladinović, Ivana. (2016). In language teaching nothing is white or black, It is believed that there is a big grey area in between: A Response of Michael W. Marek. (2014) Findings. Serbia: University of Kragujevac.

Nguyen, T. T. T. (2017). Integrating culture into language teaching and learning: Learner outcomes. The Reading Matrix: An International Online Journal, 17(1), 145-155.

Nur, A. C., \& Ratmawati, T. (2019, April). The Curriculum Development Based on the Indonesian National Qualification Framework. In 1st International Conference on Advanced Multidisciplinary Research (ICAMR 2018) (pp. 241-244). Atlantis Press.

Oliver, M., \& Trigwell, K. (2005). Can 'blended learning'be redeemed?. E-learning and Digital Media, $2(1), 17-26$.

Ramli, M.A. (2017). Konsep Budaya. Available at Page 18. Retrieved February 20, 2017 from https://www.academia.edu/

Runnisa, A. (September 25, 2018). 10 Seni dan Budaya Indonesia yang juga terkenal di Dunia dan juga telah diakui oleh UNESCO. Retrieved August 7, 2019 from http://www.ulinulin.com/posts/

Sanjaya, W. (2013). Penelitian Pendidikan: Jenis, Metode dan Prosedur. Jakarta: Kencana Prenada Media Group.

Setiadi, H. (2017). Designing a Supplementary Reading Using Cultural Language Learning Approach (CLLA). International Journal for Innovation Education and Research, 5(8), 111-128. doi:10.31686/ijier.vol5.iss8.794.

Sheppard, B. (2019). Checking Your Analytic Performance Rubrics for a Halo Effect. ORTESOL Journal, 36, 28-33.

Sheppard, R. (2015). Rubrics for Integrated Assessment. Retrieved July 20, 2019 from https://blogs.newschool.edu/unchartedtesol.

Siorpaes, K., \& Simperl, E. (2010). Human intelligence in the process of semantic content creation. World Wide Web, 13(1), 33-59.

Smith, K., \& Hill, J. (2019). Defining the nature of blended learning through its depiction in current research. Higher Education Research \& Development, 38(2), 383-397.

Sukmadinata, N.S. (2007). Metode Penelitian Pendidikan. Bandung: PT. Remaja Rosda Karya.

Tawil, H. (December, 2018). The Blended Learning Approach and Its Application in Language Teaching. International Journal of Language and Linguistics, 5(4). doi:10.30845/ijll.v5n4p6.

Thompson, J. (2016). 6 Blended Learning Models: When Blended Learning Is What's Up For Successful Students Retrieved July 20, from https://elearningindustry.com/. 
Tosuncuoglu, I. (2018). Importance of Assessment in ELT. Journal of Education and Training Studies, 6(9), 163-167.

van Ek, J. A. (1972). Analysis of the Problems Involved in Defining, in Operational Terms, a Basic Competence Level (or Threshold Level) in Foreign Language Learning by Adults.

Watson, S. (February, 2019). Higher-Order Thinking Skills (HOTS) in Education -Teaching Students to Think Critically. ThoughtCo. (the Dotdash publishing family). Available May 14, 2020 from https://www.thoughtco.com/higher-order-thinking-skills-hots-education-3111297.

Wayang Indonesia. (2010). UNESCO Akui Wayang sebagai Master Piece Dunia. Retrieved August 7, 2019 from https://wayang.wordpress.com/

Widyastutieningrum, S. R. (2018). Reviving wayang orang sriwedari in Surakarta: Tourism-oriented performance. Asian Theatre Journal, 35(1), 100-111.

Yulkifli, Y., Ningrum, M. V., \& Indrasari, W. (2019). The Validity of Student Worksheet Using InquiryBased Learning Model with Science Process Skill Approach for Physics Learning of High School. Jurnal Penelitian \& Pengembangan Pendidikan Fisika 5(2), 155-162. 